UDC $\quad 622.341 .1-188: 669.094 .1$

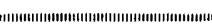

論文

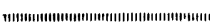

\title{
水素・水蒸気混合ガスによるへマタイト微粒子の 還元におよぼす予備還元の影響*
}

\author{
中野 義夫**. 石田愈***. 白井隆***

\begin{abstract}
Effect of Pre-reduction on the Reduction of Hematite Powder by $\mathrm{H}_{2}-\mathrm{H}_{2} \mathrm{O}$ Mixtures
\end{abstract}

Yoshio Nakano, Masaru Ishida, and Takashi SHIRAI

\section{Synopsis:}

The effect of pre-reduction of sintered hematite powder on the subsequent reduction to iron was investigated. Both the pre-reduction and the subsequent reduction were carried out at $900^{\circ} \mathrm{C}$, but the ratio of the partial pressures, $p_{\mathrm{H}_{2}} / p_{\mathrm{H}_{2} \mathrm{O}}$, in the reducing gas mixtures changed very widely.

When the hematite powder was pre-reduced to magnetite, the rate of the subsequent reduction from magnetite to wustite as well as that from wustite to iron was retarded significantly. And topochemical progress of iron-wustite interface could be observed as in the case of the reduction of original hematite without pre-reduction.

By pre-reducing the hematite powder to wustite, the subsequent reduction proceeded much faster than the reduction of hematite without pre-reduction, especially when the concentration of hydrogen was much higher than that of water vapor. Under such conditions, the reduction from wustite to iron progressed nontopochemically. As the concentration of water vapor became high, however, the reduction began to progress rather topochemically.

By plotting the rate of reduction from wustite to iron against the ratio of hydrogen to water-vapor concentrations, it was found that the equilibrium between wustite and iron shifted apparently to the side of high concentration of hydrogen by such pre-reduction.

\begin{abstract}
1. 緒
言

気体ならびに液体が関与する均一反応では一般にそれ らの物質の生成方法によつて物理的, 化学的な差異は示 さない，ところが固体が関与する不均一反応では, 同じ 組成のものであつてもそれが生成される条件, 履歴など によつて固体の物理的ならびに化学的な性状が著しく異 なり, 反応速度も異なつてくる. 特に, 酸化鉄の還元反 応はへマタイト $\left(\mathrm{Fe}_{2} \mathrm{O}_{3}\right)$ がマグネタイト $\left(\mathrm{Fe}_{3} \mathrm{O}_{4}\right)$, ウ スタイト $\left(\mathrm{Fe}_{1-\mathrm{y}} \mathrm{O}\right)$ を経て鉄にまで還元される多段反応 であるために, 前の反応の反応条件が引続いて起こる後 の反応に影響を及ぼすことは当然と考えられる.

これまで酸化鉄ペレットあるいは粒子層の水素還元に
\end{abstract}

対して計算された結果によると，ほとえどの場合ペレッ 卜あるいは粒子層内部の水蒸気濃度は外部よりかなり高 くなつていることが示されている1)2). その結果, 中間生 成物であるマグネタイトあるいはウスタイトは高い水蒸 気濃度の混合ガス中で生成され, その後, より低い水蒸 気浱度のもとで鉄にまで還元されることになる。これま での研究はあらかじめ調整されたマグネタイトやウスタ イトの単結晶ならびに粒子を使うことが多く3) 5)，この ような高い水蒸気浱度のもとで生成されたマグネタイト やウスタイトが，それよりも低い水蒸気濃度のもとで引 続いて起こる鉄一の還元反応にいかなる影響を及ぼすか についての研究は全く見あたらない.

本研究においては, ヘマタイト粒子を高い水蒸気濃度

* 昭和 50 年 6 月 4 日受付 (Received June 4, 1975)

** 東京工業大学資源化学研究所 (Research Laboratory of Resorces Utilization, Tokyo Institute of Technology)

*** 東京工業大学資源化学研究所工博 (Research Laboratory of Resorces Utilization, Tokyo Institute of Technolagy 2-12-1 Okayama Meguro-ku Tokyo 152) 


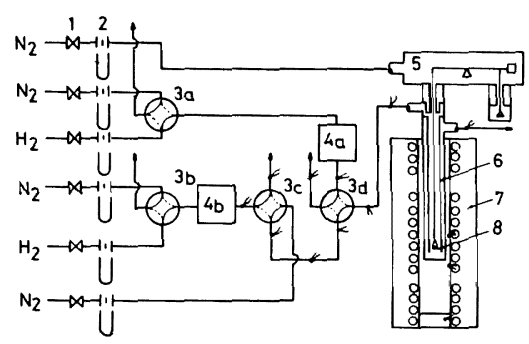
1) Needle valve
4) Saturator
7) Electric furnace
2) Capillary flow meter 5) Micro-ballance 8) Platinum cage
3) Four-way valve
6) Quartz tube

Fig. 1. Outline of experimental apparatus.

の水素-水蒸気混合ガスのもとでマグネタイトあるいは ウスタイトの段階まで尒哄還元し，引続いて，これより 水蒸気濃度の低い混合ガスにより鉄をで還元する実験を 行なつたところ，予備還元が後の鉄一の還元反応速度な らびに反応の進行形態に顕著に影響を及ぼすことが判明 したのでここに報告する.

\section{2. 酸化鉄粒子の還元実験}

実駼装置の概略図を Fig. 1 に示す．使用した自動記 録型々ク口熱天称は島津轅 (RMB-50) のものであるが 水蒸気ガスを流せるように反応管 $(6)$ を二重管とし，ま た，還元ガスの温度が所定の温度まで十分上がるよう反 応管を長くするなどの改良をほどこした，さらに一定温 度域をつくるために電気炉を改良した。この反応管 (6) は透明石英製で，外管は長さ $460 \mathrm{~mm}$, 内径 $24 \mathrm{~mm}$, 内 管は長さ $455 \mathrm{~mm}$, 内径 $14.5 \mathrm{~mm}$ である. 80 メッシュ の白金網で作つた直径 $4 \mathrm{~mm}$, 深さ $3 \mathrm{~mm}$ のカゴ (8) の内側に 1 5 $\mu$ の石英ガラス緎維を薄く敷き, この上 に後で述べる方法で調製したへマタイト微粒子をのせ， このカゴを熱天科より吊してある石英ガラス製の棒（直 径 $0.04 \mathrm{~cm}$ ) 先端のフックに連結させる. カゴの周囲の 温度を測定するために，白金一白金口ジウム熱電対がカ ゴの下約 $5 \mathrm{~mm}$ の位置に取りつけられている，本実験は すべて一定温度, $900^{\circ} \mathrm{C} て ゙$ 行なつた.

還元ガスである水素一水蒸気混 合ガスは前報6) と同様 に蒸留水を満してある飽和器 $\left(4 \mathrm{a}, 4_{\mathrm{b}}\right)$ に水素ガスを通 すことによつて得た. 飽和器内での水温を一定温度に保 つために，その加熱に用いているマントルヒーターの電 压は SCR 電圧調整器を用いて PID 制御されている. 混合ガス中での水蒸気モル分率は，この混合ガスをシリ カゲルを充继したU字管に通すことにより，一定時間水

蒸気を吸収させ,その重量增加より決定した・この方法に よつて測定した水蒸気のモル分算は飽和器内の水温より 計算したモル分率とよく一致した。本実験では反応途中 で水素-水蒸気混合ガス中の水蒸気 濃度を瞬時に切り換 えることができるよう，饱和器を 2 個 $\left(4_{\mathrm{a}}, 4_{\mathrm{b}}\right)$ 設けた。 飽和器 $\left(4_{\mathrm{a}}\right)$ の温度は飽和器 $\left(4_{\mathrm{b}}\right)$ の温度より高く保ち まず, Fig. 1 の $\mathrm{H}_{2} \rightarrow 3_{\mathrm{a}} \rightarrow 4_{\mathrm{a}} \rightarrow 3_{\mathrm{d}} \rightarrow$ 反応管の経路によつ て，カゴにのせてあるへマタイト試料を水蒸気濃度の高 い水素-水蒸気-窒素混合ガスでマグネタイト $\left(\mathrm{Fe}_{3} \mathrm{O}_{4}\right)$ あ るいはウスタイトまで $10 \mathrm{~min}$ 予備還元を行なつた後, 4 方コック ( $\left.3_{\mathrm{d}}\right)$ を切りか光 $\mathrm{H}_{2} \rightarrow 3_{\mathrm{b}} \rightarrow 4_{\mathrm{b}} \rightarrow 3_{\mathrm{c}} \rightarrow 3_{\mathrm{d}} \rightarrow$ 反応 管の経路を使い，予備還元で生成されたマグネタイトあ るいはウスタイトを途中不活性ガスにさらすことなく, 引続き鉄にまで還元した．混合ガス中に若干の窒素が含 まれているのは水蒸気が天科部分（Fig.1の5) に入ら ないようにするために窒素ガスを全流量の 2.8 ４.6\%， 天称室から反応管に送りこんでいることによる. 反忘管 の内管内におけるガス速度は $5.5 \sim 11 \mathrm{~cm} / \mathrm{sec}$ (N.T.P.)

とした.

また，いくつかの実験においては，還元途中所定の時 間に 4 方コック (3c) を切り換えて窒素ガスを $3_{\mathrm{c} \rightarrow 3 \mathrm{~d} \rightarrow}$ 反応管の経路に流すことにより反応を止めて，この試料 をメタノ一ル中に入れ，再酸化を防いで金属顕徴鏡によ る観察を行なつた.

本実験で使用した $\alpha$-ヘマタイト $\left(\alpha-\mathrm{Fe}_{2} \mathrm{O}_{3}\right)$ 試料は市 販の酸化鉄 $\left(\mathrm{Fe}_{2} \mathrm{O}_{3}\right)$ 粉（和光純薬製）を $1300^{\circ} \mathrm{C}$ で 1 $\mathrm{hr}$ 焼結を行ない, 冷却後粉砕したものである.この調製 した試料の純度は $99.6 \%$, そして平均径は $8.1 \mu$ であ つた. 約 $30 \mathrm{mg}$ の酸化鉄試料を充填した白金カゴを反応 管内に吊し，還元反応を行なつた。還元による試料の重 量変化は連続的に記録計に記録され，この重量变化曲線 の傾きより還元速度を計算した。

\section{3. 実験結果ならびに考察}

\section{$3 \cdot 1$ 予備還元がその後の鉄までの反応におよぼす影響}

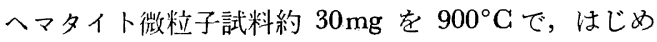
から水蒸気濃度の低い $P_{\mathrm{H}_{2} \mathrm{O}} /\left(P_{\mathrm{H}_{2}}+P_{\mathrm{H}_{2} \mathrm{O}}\right)=0.0152$ の水 素-水蒸気-䇪素混合ガス $\left(P_{\mathrm{H}_{2}}=0.940 \mathrm{~atm}, \quad P_{\mathrm{H}_{2} \mathrm{O}}=\right.$ $\left.0.0145 \mathrm{~atm}, P_{\mathrm{N}_{2}}=0.046 \mathrm{~atm}\right)$ で直接鉄にまで還元し たときの還元率曲線を Fig. 2 に○印によつて示した. 反応開始より $90 \%$ の僈元率 $\left(X_{\mathrm{HI}}=0.9\right)$ に達するのに 約 $1.5 \mathrm{~min}$ の時間を要している. なお, 縱軸の $X_{\mathrm{HI}}$ は ヘマタイト $\left(\mathrm{Fe}_{2} \mathrm{O}_{3}\right)$ から鉄までの総括還元率で，へマタ イトでは零, マグネタイト $\left(\mathrm{Fe}_{3} \mathrm{O}_{4}\right)$ では $0.11(=1 / 9)$, 鉄 では 1 の值をとる. 非化学量論化合物であるウスタイト 


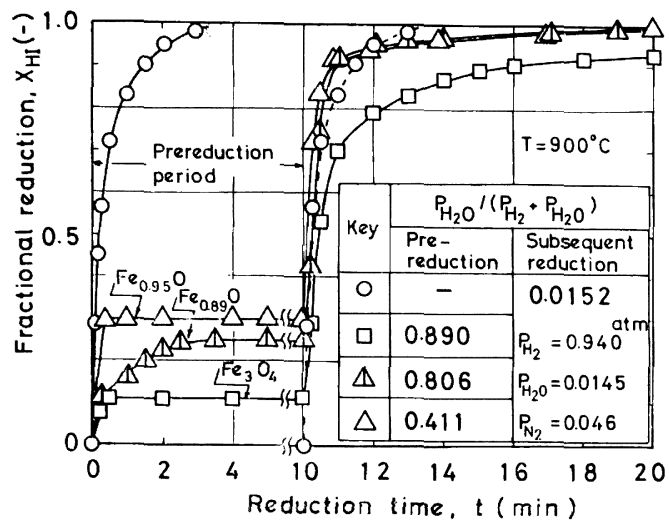

Fig. 2. Effect of pre-reduction to magnetite or wustite on the subsequent reduction to iron, $P_{\mathrm{H}_{2} \mathrm{O}} /\left(P_{\mathrm{H}_{2}}+P_{\mathrm{H}_{2} \mathrm{O}}\right)=0.0152$.

$\left(\mathrm{Fe}_{1-\mathrm{y}} \mathrm{O}\right)$ に対する $X_{\mathrm{HI}}$ は $900^{\circ} \mathrm{C}$ の温度において約 0.25 から 0.30 まで変わる7).

それに対して, Fig. 2 に印で示すように同じへマ タイト微粒子試料を $P_{\mathrm{H}_{2} \mathrm{O}} /\left(P_{\mathrm{H}_{2}}+P_{\mathrm{H}_{2} \mathrm{O}}\right)=0.890$ の組成 の混合ガス $\left(P_{\mathrm{H}_{2}}=0.107 \mathrm{~atm}, P_{\mathrm{H}_{2} \mathrm{O}}=0.865 \mathrm{~atm}, P_{\mathrm{N}_{2}}=\right.$ $0.028 \mathrm{~atm}$ ) で $10 \mathrm{~min}$ 間予備還元すると $X_{\mathrm{HI}}=0.11$ ( グネタイト）まで還元が進み，引続いて水蒸気浱度を $P_{\mathrm{H}_{2} \mathrm{O}} /\left(P_{\mathrm{H}_{2}}+P_{\mathrm{H}_{2} \mathrm{O}}\right)=0.0152$ と低くして鉄まで還元を行 なつたところ，その還元速度はへマタイト試料を直接鉄 まで還元させた場合に比べて非常に遅くなり $X_{\mathrm{HI}}=0.11$ より $X_{\mathrm{HI}}=0.90$ まで達するのに約 $6.5 \mathrm{~min}$ もの時間を 要している.

また, 同じへマタイト微粒子試料を $P_{\mathrm{H}_{2} \mathrm{O}} /\left(P_{\mathrm{H}_{2}}+P_{\mathrm{H}_{2} \mathrm{O}}\right)$ $=0.806$ の混合ガス $\quad\left(P_{\mathrm{H}_{2}}=0.185 \mathrm{~atm}, \quad P_{\mathrm{H}_{2} \mathrm{O}}=0.769\right.$ atm, $\left.P_{\mathrm{N}_{2}}=0.046 \mathrm{~atm}\right)$ で予備還元すると $X_{\mathrm{HI}}=0.25$ ま で還元が進えだ，組成が均一と仮定すると，この還元率 は $\mathrm{Fe}_{0.89} \mathrm{O}$ の組成に対応している. 一方, それより水蒸 気濃度の低い $P_{\mathrm{H}_{2} \mathrm{O}} /\left(P_{\mathrm{H}_{2}}+P_{\mathrm{H}_{2} \mathrm{O}}\right)=0.411$ の混合ガス ( $\left.P_{\mathrm{H}_{2}}=0.562 \mathrm{~atm}, P_{\mathrm{H}_{2} \mathrm{O}}=0.392 \mathrm{~atm}, P_{\mathrm{N}_{2}}=0.046 \mathrm{~atm}\right)$ で予備還元すると $X_{\mathrm{HI}}=0.30$ まで還元が進み，この還 元率は $\mathrm{Fe}_{0.95} \mathrm{O}$ の組成に対応している.これらマグネタ イトーウスタイトの平衡に近いウスタイトならびにウス タイトー鉄の平衡に近いウスタイトまで予備還元した試 料を, 引続いて水蒸気濃度が $P_{\mathrm{H}_{2} \mathrm{O}} /\left(P_{\mathrm{H}_{2}}+P_{\mathrm{H}_{2} \mathrm{O}}\right)=0.0152$ と低い混合ガスで鉄へ袈元したときの速度はむしろ速く

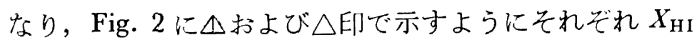
$=0.25$ ならびに 0.30 より $X_{\mathrm{HI}}=0.9$ まで達するのに 約 $0.75 \mathrm{~min}$ の時間を要した.ただしこの場合， $X_{\mathrm{HI}}=$ 0.90 以上になると還元速度は急激に減少してくる.

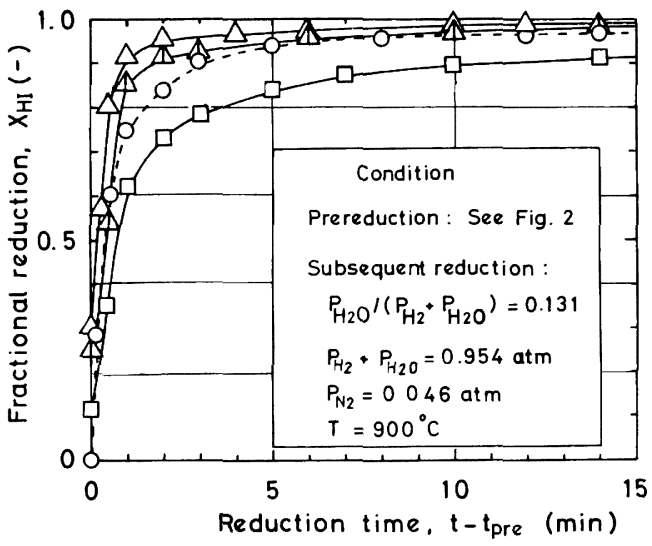

Fig. 3. Effect of pre-reduction to magnetite or wustite on the subsequent reduction to iron, $P_{\mathrm{H}_{2} \mathrm{O}} /\left(P_{\mathrm{H}_{2}}+P_{\mathrm{H}_{2} \mathrm{O}}\right)=0.131$.

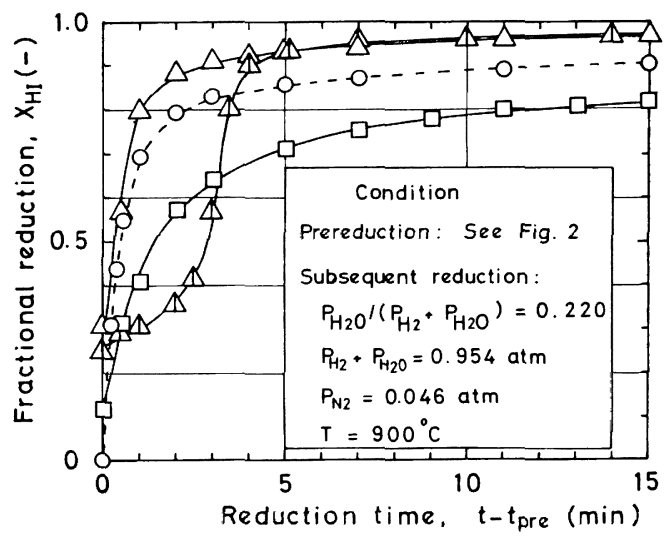

Fig. 4. Effect of pre-reduction to magnetite or wustite on the subsequent reduction to iron, $P_{\mathrm{H}_{2} \mathrm{O}} /\left(P_{\mathrm{H}_{2}}+P_{\mathrm{H}_{2} \mathrm{O}}\right)=0.220$.

Fig. 3 は Fig. 2 に示したと同じ 3 種類の条件で 10 min 間予備還元した試料ならびにへマタイト微粒子試 料そのままを $P_{\mathrm{H}_{2} \mathrm{O}} /\left(P_{\mathrm{H}_{2}}+P_{\mathrm{H}_{2} \mathrm{O}}\right)=0.131$ の混合ガス $\left(P_{\mathrm{H}_{2}}=0.829 \mathrm{~atm}, P_{\mathrm{H}_{2} \mathrm{O}}=0.125 \mathrm{~atm}, P_{\mathrm{N}_{2}}=0.046 \mathrm{~atm}\right)$ で鉄まで還元を行なつたときの結果である.ただし， 予備還元中の $X_{\mathrm{HI}}$ の変化は Fig. 2 と同じであるため 省略し, 予僃還元後の時間 $\left(t-t_{\mathrm{pre}}\right)$ に対する $X_{\mathrm{HI}}$ の 変化のみを示してある. 各々の還元率曲線の傾向は大体 Fig. 2 と同じである.

さらに Fig. 4 に示すように $P_{\mathrm{H}_{2} \mathrm{O}} /\left(P_{\mathrm{H}_{2}}+P_{\mathrm{H}_{2} \mathrm{O}}\right)=$ $0.220\left(P_{\mathrm{H}_{2}}=0.744 \mathrm{~atm}, P_{\mathrm{H}_{2} \mathrm{O}}=0.210 \mathrm{~atm}, P_{\mathrm{N}_{2}}=0.046\right.$ $\mathrm{atm})$ と水蒸気の濃度を高くして鉄にまで還元すると， $X_{\mathrm{HI}}=0.25\left(\mathrm{Fe}_{0.89} \mathrm{O}\right)$ まで予備還元されたウスタイトの その後の還元染曲線は顕著なシグモイド型となり， $X_{\mathrm{HI}}$ 


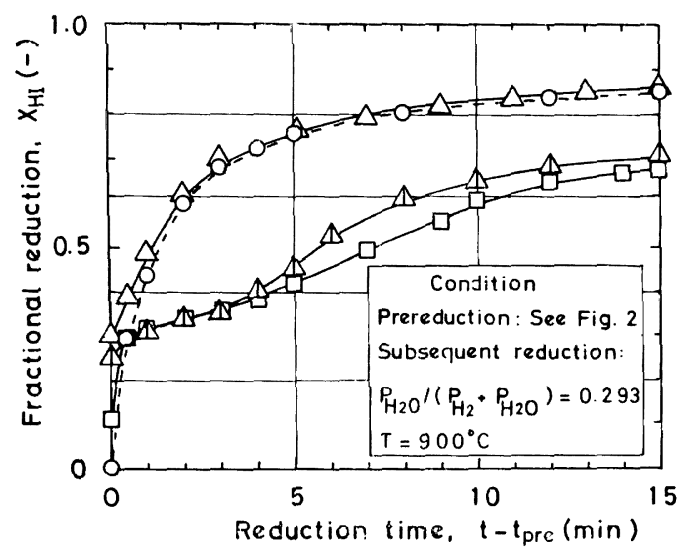

Fig. 5. Effect of pre-reduction to magnetite or wustite on the subsequent reduction to iron, $P_{\mathrm{H}_{2} \mathrm{O}} /\left(P_{\mathrm{H}_{2}}+P_{\mathrm{H}_{2} \mathrm{O}}\right)=0.293$.

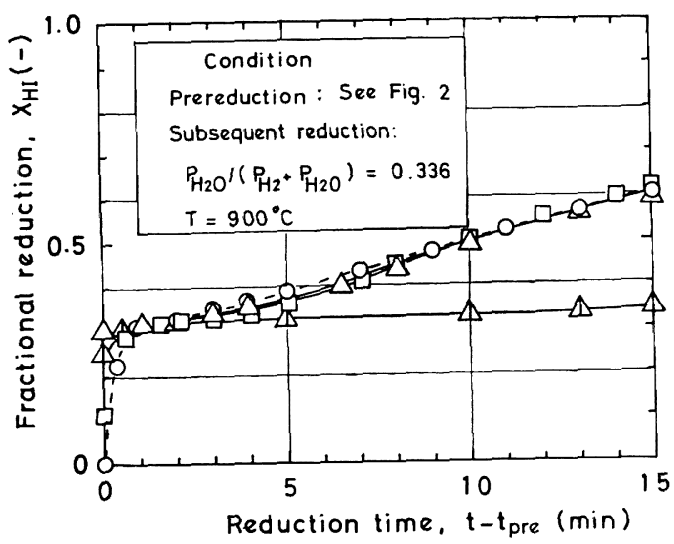

Fig. 6. Effect of pre-reduction to magnetite or wustite on the subsequent reduction to iron, $P_{\mathrm{H}_{2} \mathrm{O}} /\left(P_{\mathrm{H}_{2}}+P_{\mathrm{H}_{2} \mathrm{O}}\right)=0.336$.

$=0.4$ あたりまでは還元されにくいが， $X_{\mathrm{HI}}=0.4$ を過 ぎると急速に還元が進えでいる。

Fig. 5 に示すように $P_{\mathrm{H}_{2} \mathrm{O}} /\left(P_{\mathrm{H}_{2}}+P_{\mathrm{H}_{2} \mathrm{O}}\right)=0.293\left(P_{\mathrm{H}_{2}}\right.$ $\left.=0.674 \mathrm{~atm}, P_{\mathrm{H}_{2} \mathrm{O}}=0.280 \mathrm{~atm}, P_{\mathrm{N}_{2}}=0.046 \mathrm{~atm}\right)$ とさ らに水蒸気濃度を高くして鉄にまで還元すると， $X_{\mathrm{HI}}=$ 0.11 (マグネタイト) まで予備還元した試料においても $X_{\mathrm{HI}}=0.24 \sim 0.31$ でいつたん還元速度が遅くなり， $X_{\mathrm{HI}}$ $=0.25\left(\mathrm{Fe}_{0.89} \mathrm{O}\right)$ まで予備還元されたウスタイトの還元 率曲線とほぼ同様なシグモイド曲線を描くようになる。 一方，予備還元なしに直接鉄まで還元した場合と， $X_{\mathrm{HI}}$ $=0.30\left(\mathrm{Fe}_{0.95} \mathrm{O}\right)$ まで一度予備還元した場合とは, 還元 率曲線が似ており，両者ともシグモイド型になつていな い.

ところが，Fig. 6 に示すようにさらに水蒸気濃度を
$P_{\mathrm{H}_{2} \mathrm{O}} /\left(P_{\mathrm{H}_{2}}+P_{\mathrm{H}_{2} \mathrm{O}}\right)=0.336 \quad\left(P_{\mathrm{H}_{2}}=0.633 \mathrm{~atm}, \quad P_{\mathrm{H}_{2} \mathrm{O}}=\right.$ $\left.0.321 \mathrm{~atm}, P_{\mathrm{N}_{2}}=0.046 \mathrm{~atm}\right)$ と鉄-ウスタイトの平衡水 蒸気濃度近くまで高くして鉄にまで迠元すると予備還元 なしに鉄まで反応した場合と， $X_{\mathrm{HI}}=0.30\left(\mathrm{Fe}_{0.95} \mathrm{O}\right)$ ま で予備還元した場合と， $X_{\mathrm{HI}}=0.11$ (マグネタイト)まで 予備還元した場合の還元率曲線は，約 $X_{\mathrm{HI}}=0.3$ を越え るとどの場合もほぼ同じ顕著なシグモイド型の曲線とな つている．このような高水蒸気濃度のもとで鉄までの還 元が進む場合には，予備還元なしに鉄まで逧元しても， マグネタイトまで予備還元しその後鉄にまで還元しても 予備還元による著しい差はなくなつていく傾向にある. しかし， $X_{\mathrm{HI}}=0.25\left(\mathrm{Fe}_{0.89} \mathrm{O}\right)$ まで予備還元されたウスタ イトがその後鉄に還元される場合にはほかの場合より著 しく誘導期間の長い還元率曲線を示している.

\section{2 疅元速度の僄元率に対する変化}

Fig. 7 は，予備還元なしに直接鉄まで還元を行なつた 場合に対して, Fig. 2 から Fig. 6 の各々の還元率曲線 の傾きから計算した還元速度 $d X_{\mathrm{HI}} / d t$ と還元率 $X_{\mathrm{HI}}$ と の関係を示している．還元開始より $X_{\mathrm{HI}}=0.1$ あたりま ではほとんど一定の還元速度を示し還元がそれ以上進む と還元速度は減少し始め, その減少の程度は水蒸気分王

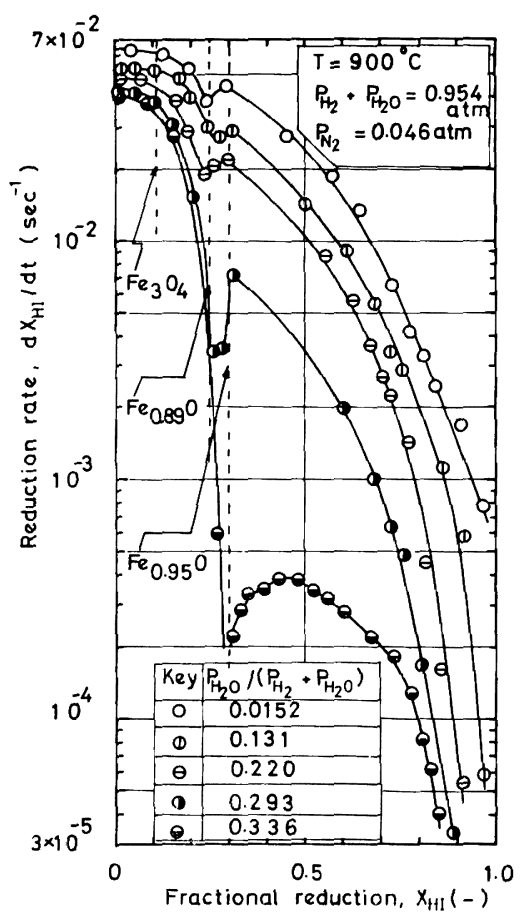

Fig. 7. Reduction rate of hematite powder, when reduced directly to iron in $\mathrm{H}_{2}-\mathrm{H}_{2} \mathrm{O}$ mixtures. 


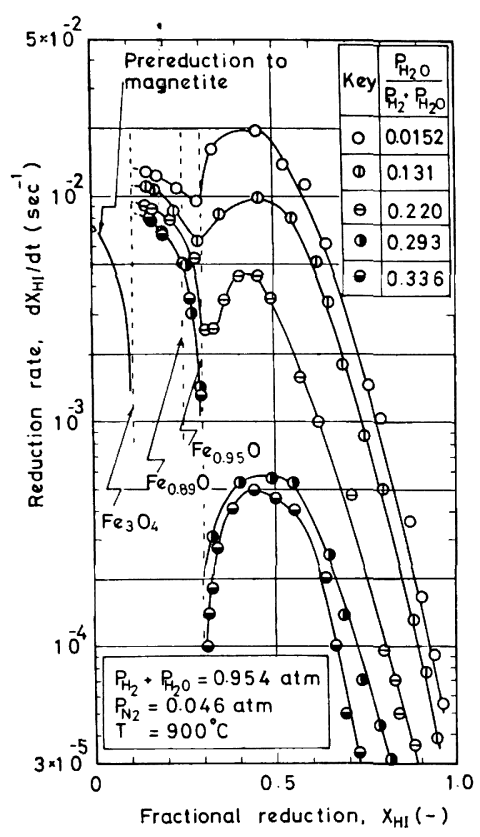

Fig. 8. Reduction rate of pre-reduced magnetite, when reduced subsequently to iron in $\mathrm{H}_{2}-\mathrm{H}_{2} \mathrm{O}$ mixtuses.

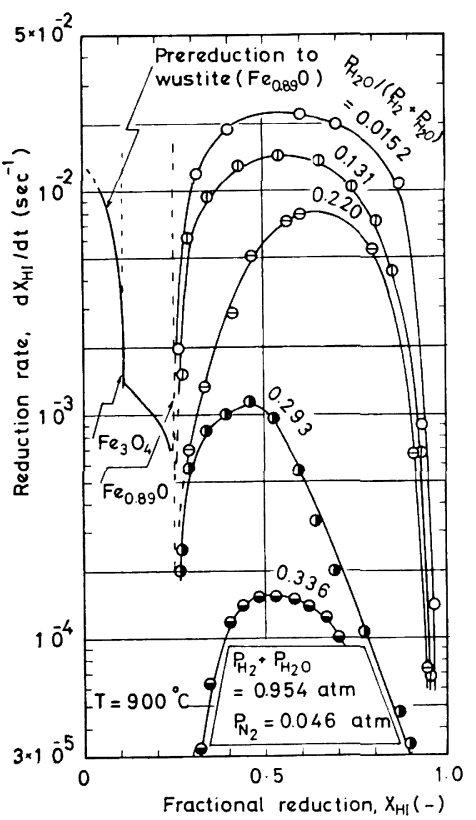

Fig. 9. Reduction rate of pre-reduced wustite, $\mathrm{Fe}_{\mathbf{0}}{ }_{89} \mathrm{O}$, when reduced subsequently to iron in $\mathrm{H}_{2}-\mathrm{H}_{2} \mathrm{O}$ mixtures.

が増大し，水素分圧が減少するにつれて顕著になつてい る. その後還元速度は再び大きくなり， $X_{\mathrm{HI}}=0.3$ あた

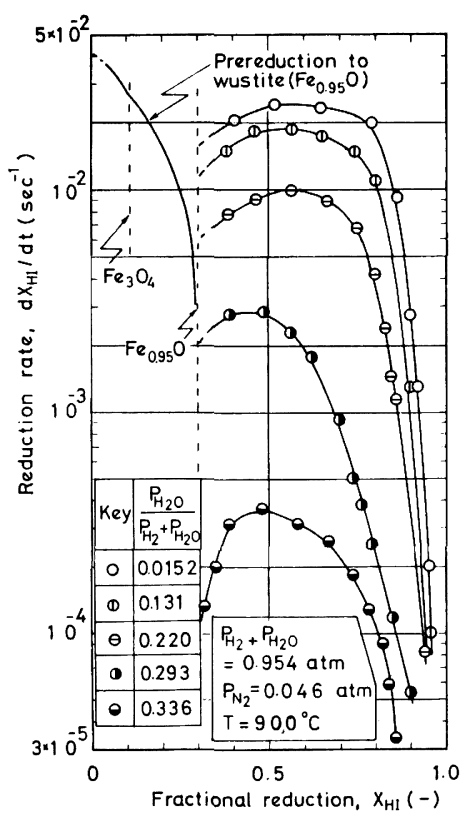

Fig. 10. Reduction rate of pre-reduced wustite, $\mathrm{Fe}_{0.95} \mathrm{O}$, when reduced subsequently to iron in $\mathrm{H}_{2}-\mathrm{H}_{2} \mathrm{O}$ mixtures.

りで極大值を取り，それ以後は単調に減少する．ただし $P_{\mathrm{H}_{2} \mathrm{O}} /\left(P_{\mathrm{H}_{2}}+P_{\mathrm{H}_{2} \mathrm{O}}\right)=0.336$ と鉄-ウスタイトの平衡近く の水蒸気濃度で鉄まで還元した場合のようにウスタイト から鉄に至る還元率曲線がシグモイド型となる場合には 反応速度の極大值が $X_{\mathrm{HI}}=0.45$ あたりに現われている。

一方, あらかじめ $P_{\mathrm{H}_{2} \mathrm{O}} /\left(P_{\mathrm{H}_{2}}+P_{\mathrm{H}_{2} \mathrm{O}}\right)=0.890$ の混合 ガスで $X_{\mathrm{HI}}=0.11$ (マグネタイト) まで予備還元を行な い, さらに $P_{\mathrm{H}_{2} \mathrm{O}} /\left(P_{\mathrm{H}_{2}}+P_{\mathrm{H}_{2} \mathrm{O}}\right)=0.0152 \sim 0.336$ の混合 ガスで鉄まで還元を行なつた場合の反応速度と還元率と の関係を Fig. 8に示す. $X_{\mathrm{HI}}=0.11$ から $X_{\mathrm{HI}}=0.3$ あ たりまでは，還元が進むにつれて還元速度は減少してい るが， $X_{\mathrm{HI}}=0.3$ を越えると再び速度は増大する. そし て， $X_{\mathrm{HI}}=0.4$ から 0.5 のあたりで極大值を取り，それ 以後は単調に減少している. このようにマグネタイトま で予供還元された試料は水蒸気濃度の低いときでも $X_{\mathrm{HI}}$ $=0.3$ から 0.4 あたりまで還元速度が上昇しており，

Fig. 7 に示したへマタイト試料を直接鉄まで還元した場 合と異なつている.さらに，各還元率での還元速度は Fig. 7 の直接に鉄まで還元した場合に比較して非常に小 さくなつており, 予備還元がその後の還元速度に顕著に 影響することを示している。

ヘマタイト微粒子試料を $P_{\mathrm{H}_{2} \mathrm{O}} /\left(P_{\mathrm{H}_{2}}+P_{\mathrm{H}_{2} \mathrm{O}}\right)=0.806$ の 混合ガスで $X_{\mathrm{HI}}=0.25$ の $\mathrm{Fe}_{\mathbf{0}}{ }_{89} \mathrm{O}$ に相当するウスタイ 
トまで予備還元を行なつた場合の還元 速度と, その後 $P_{\mathrm{H}_{2} \mathrm{O}} /\left(P_{\mathrm{H}_{2}}+P_{\mathrm{H}_{2} \mathrm{O}}\right)=0.0152 \sim 0.336$ の混合ガスで鉄まで 還元を行なつた場合の還元速度とを Fig. 9 に示してあ る. 予䚚還元後の還元速度は急激に增大し, 特に水蒸気 濃度が $P_{\mathrm{H}_{2} \mathrm{O}} /\left(P_{\mathrm{H}_{2}}+P_{\mathrm{H}_{2} \mathrm{O}}\right)=0.0152 \sim 0.220$ と低いとき には約 $X_{\mathrm{HI}}=0.6$ で極大值を取り， $X_{\mathrm{HI}}=0.85$ あたりを 越えるまで還元速度の急な低下は見られず, $X_{\mathrm{HI}}=0.5$ か ら 0.9 の範囲では Fig. 7 に示した直接に鉄まで還元し た場合よりも大きな還元速度を示している。

ヘマタイト溦粒子を $P_{\mathrm{H}_{2} \mathrm{O}} /\left(P_{\mathrm{H}_{2}}+P_{\mathrm{H}_{2} \mathrm{O}}\right)=0.411$ の混 合ガスで $X_{\mathrm{HI}}=0.30$ の $\mathrm{Fe}_{0.95} \mathrm{O}$ に相当するウスタイト まで予備還元を行なつた場合の還元速度と引続き $P_{\mathrm{H}_{2} \mathrm{O}} \mathrm{O}$ $\left(P_{\mathrm{H}_{2}}+P_{\mathrm{H}_{2} \mathrm{O}} \mathrm{O}=0.0152 \sim 0.336\right.$ の混合ガスで鉄まで還元 を行なつた場合の還元速度とを Fig. 10 に示してある. この場合，直接に鉄にまで還元したときの Fig. 7 とあ らかじめ $X_{\mathrm{HI}}=0.25$ のウスタイトまで予借還元した試 料を還元したときの Fig. 9 との中闆の傾向を示してい る.

\section{3 䶊元速度と平衡ガス組成との関保}

ヘマタイトからマグネタイトに至る還元率 $X_{\mathrm{HI}}=0.05$ での還元速度と水蒸気分压 $P_{\mathrm{H}_{2} \mathrm{O}} /\left(P_{\mathrm{H}_{2}}+P_{\mathrm{H}_{2} \mathrm{O}}\right)$ との関係 を Fig. 11 に示す. 水蒸気分圧が増大寸ると, 還元速度 はやや下に凸の曲線を描いて減少し, その延長線と横軸 との交点 (図中の黑丸印) は DARKEN らの結果7)上り求 めたへマタイトとマグネタイトとが平衡状態となるとき のガス組成 $P_{\mathrm{H}_{2} \mathrm{O}} /\left(P_{\mathrm{H}_{2}}+P_{\mathrm{H}_{2} \mathrm{O}}\right)=0.98$ に対応している. なお， $\mathrm{NABI}^{4}$ らは円柱状に成型した $\mathrm{Fe}_{2} \mathrm{O}_{3}$ 試料を水素一 水蒸気混合ガスで還元を行ないへマタイトとマグネタイ 卜の界面の移動速度は水蒸気分任が增すとともに直線的 に減少することを報告している.

マグネタイトからウスタイトに至る反応に関しては， 特に $X_{\mathrm{HI}}=0.15$ を例にとり，そのときの還元速度と水 蒸気分圧との関係を Fig. 12 に示す. 図中O印はへマタ イト試料を各水蒸気嶩度の混合ガスで還元した場合で, $P_{\mathrm{H}_{2} \mathrm{O}} /\left(P_{\mathrm{H}_{2}}+P_{\mathrm{H}_{2} \mathrm{O}}\right)=0.4$ あたりまでは還元速度は水蒸気 分压が増すとともに直線的に減少しているが，それ以上 に水蒸気分圧が高くなると下に凸の曲線を描いている。 この曲線の延長線と横軸との交点（図中の黑丸印）も DARKEN らの結果より求めたマグネタイトとウスタイト $\left(\mathrm{Fe}_{0.888} \mathrm{O}\right)$ とが平衡状態となるときのガス組成 $P_{\mathrm{H}_{2} \mathrm{O}} /$ $\left(P_{\mathrm{H}_{2}}+P_{\mathrm{H}_{2} \mathrm{O}}\right)=0.82^{7}$ に対応している. 一方, $\square$ 印は $X_{\mathrm{HI}}$ $=0.11$ まで $10 \mathrm{~min}$ 間子備還元を行ない, 引続いて鉄に まで還元した場合でヘヘマタイト試料をそのまま還元し た場合に比べて，マグネタイトからウスタイトへ行く段 階で還元速度が著しく小さくなつていることがわかる。

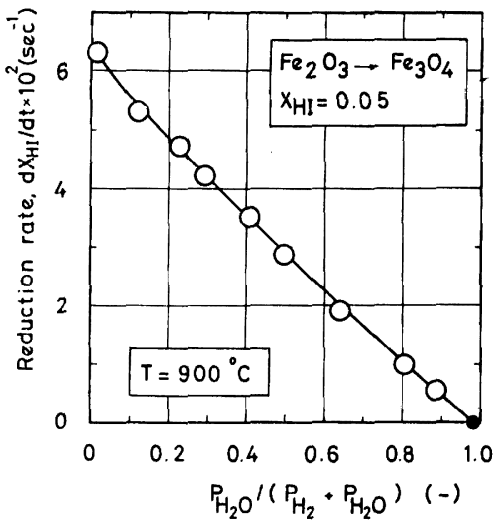

Fig. 11. Effect of partial pressure of water vapor on the reduction rate of hematite to magnetite.

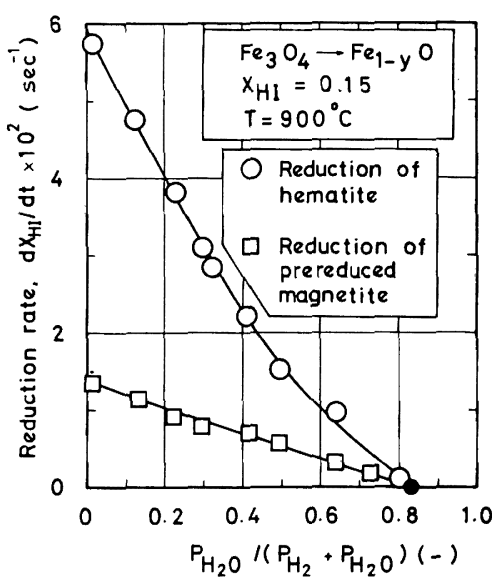

Fig. 12. Effect of partial pressure of water vapor on the reduction of magnetite to wustite.

なお，EDSTRÖM ${ }^{3)}$ は単結晶のへマタイトとマグネタイト を用いヘマタイトのほうがマグネタイトよりすみやかに 鉄に還元されることを報告しているが，本研究結果よ り，マグネタイトからウスタイトへの反応段階で還元速 度がすでに達くなつていることが判明した。

Fig. 13 はへマタイト試料を予備還元しないで直接鉄 まで還元を行なつた場合の還元率 $X_{\mathrm{HI}}=0.3,0.4,0.5$, $0.6,0.7,0.8$ ならびに 0.9 における還元速度と水蒸気 分圧との関係を示している. この直接に鉄をで還元する 場合についてはすでに前報6)において報告したとおり， 水蒸気濃度の低いところでは還元速度は水蒸気分圧が増 すとともに直線的に減少し，その延長線と横軸との交点 は平衡ガス組成 $\left.P_{\mathrm{H}_{2} \mathrm{O}} /\left(P_{\mathrm{H}_{2}}+P_{\mathrm{H}_{2} \mathrm{O}}\right)=0.388^{7}\right)$ 対応して 


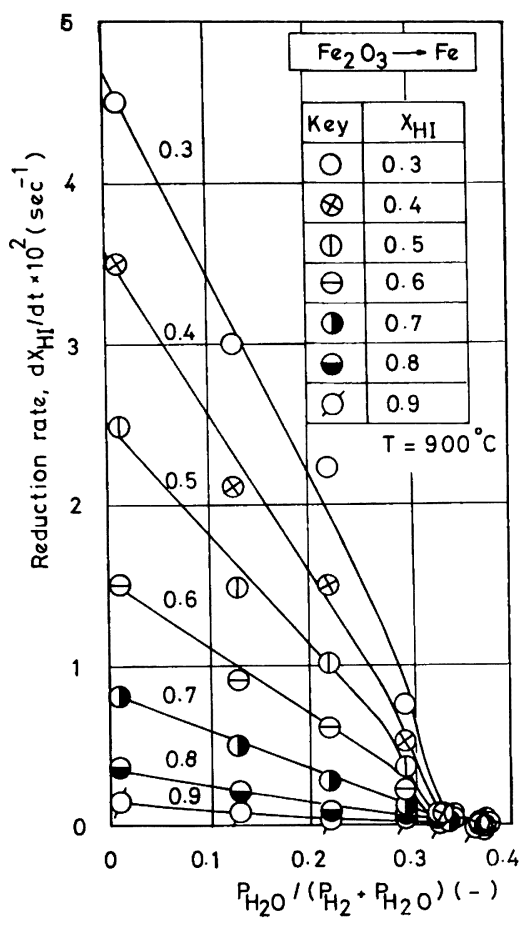

Fig. 13. Effect of partial pressure of water vapor on the reduction rate of hematite powder, when reduced directly to iron.

いるが，水蒸気分圧が約 0.3 を越えると還元速度は急激 に低下している.なお，前報で報告した還元速度に比較 して，今回の熱天科によつて測定した還元速度の方が大 きな值を示しているが，これは今回使用したへマタイト 試料と前報で使用したへマタイト試料の製造ロットが異 なつているためで，前報に示した石英管の底部に酸化鉄 微粒子を薄い層に敷き，水素一水蒸気ガスを上部より吹 きつけて還元する方法によつて今回の試料を還元した場 合にも，Fig. 13 に示したと同じ還元速度が得られるこ とを確認してある。

一方， $X_{\mathrm{HI}}=0.11$ のマグネタイト亡で予備還元を行な つた場合には，Fig. 14 に示すように，還元速度が著し く小さく現われているばかりでなく，Fig. 13 に見られ たような水蒸気分圧が約 0.3 を越したときに現われた急 激な還元速度の低下は見られずあたかも $P_{\mathrm{H}_{2} \mathrm{O}} /\left(P_{\mathrm{H}_{2}}+\right.$ $\left.P_{\mathrm{H}_{2} \mathrm{O}}\right)=0.3$ あたりが平衡組成であるかのような全体的 に下に凸の曲線を描いている。

Fig. 15, Fig. 16 にはそれぞれ $X_{\mathrm{HI}}=0.25$ のウスタイ 卜 $\left(\mathrm{Fe}_{0.89} \mathrm{O}\right), X_{\mathrm{HI}}=0.30$ のウスタイト $\left(\mathrm{Fe}_{0.95} \mathrm{O}\right)$ まで 予備還元を行なつた場合についての結果を示したが， Fig. 15 の還元速度と水蒸気分圧との関係はマグネタイ

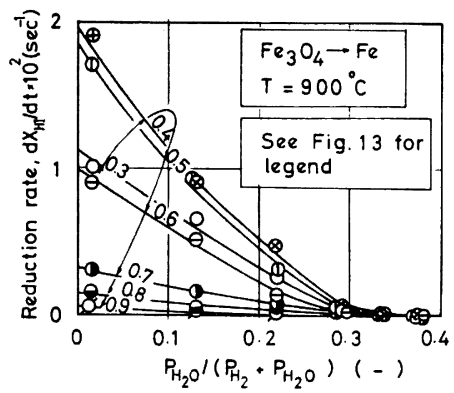

Fig. 14. Effect of partial pressure of water vapor on the reduction rate of pre-reduced magnetite, when reduced subsequently to iron.

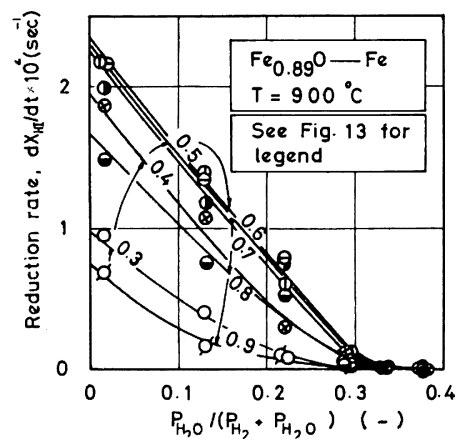

Fig. 15. Effect of partial pressure of water vapor on the reduction rate of pre-reduced wustite, $\mathrm{Fe}_{\mathbf{0 . 8 9}} \mathrm{O}$, when reduced subsequently to iron.

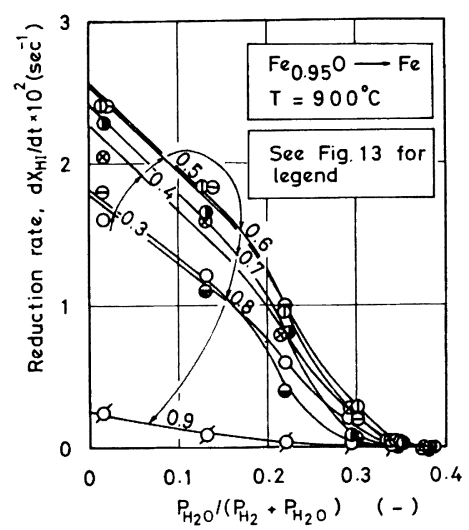

Fig. 16. Effect of partial pressure of water vapor on the reduction rate of pre-reduced wustite, $\mathrm{Fe}_{0.95} \mathrm{O}$, when reduced subsequently to iron. 
トまで予備還元した Fig. 14 と類似しており，一方 Fig. 16 は子備還元しないで直接鉄まで罡元した Fig. 13 と類 似している.

Fig. 13 から，Fig. 16 をでを比較吉ると,マグネタイ トまでの予備還元を行なつた場合には，マグネタイトか らウスタイトの段階と同慷に，ウスタイトから鉄への段 階でも還元速度は著しく低下していることがわかつた. また，Fig. 13 より Fig. 16 の図上で還元速度が零近 くになる横軸上での水蒸気濃度の值は子備還元しない場 合よりウスタイトまで予供還元した場合の方が小さく現 われ，マグネタイトまで予備還元した場合にはさらに小 さく現われており，予備還元によつてウスタイトー鉄の 平衡が見かけ上水素濃度の高い方に移動していくことが わかつた。

\section{4 顕微鏡による還元試料内部の観察}

Photo. 1-a ) は水蒸気の濃度の低い $P_{\mathrm{H}_{2} \mathrm{O}} /\left(P_{\mathrm{H}_{2}}+\right.$

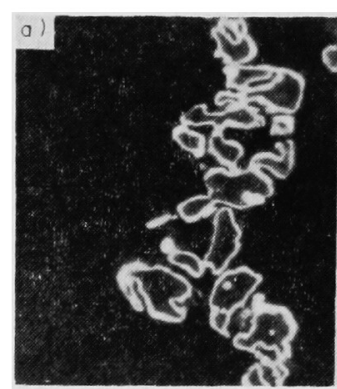

a) $X_{\mathrm{HI}}=0.63$

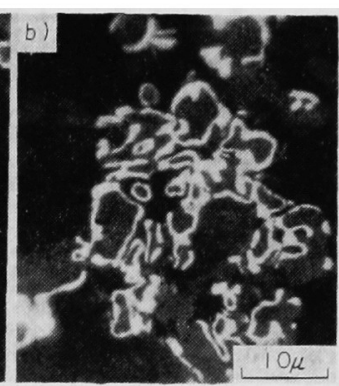

b) $X_{\mathrm{BI}}=0.56$
Photo. 1. Sectional views after partial reduction of hematite powder, when reduced directly by the mixture of (a) $P_{\mathrm{H}_{2} \mathrm{O}}$ / $\left(P_{\mathrm{H}_{2}}+P_{\mathrm{H}_{2} \mathrm{O}}\right)=0.0152$ and of (b) $P_{\mathrm{H}_{2} \mathrm{O}} /$ $\left(P_{\mathrm{H}_{2}}+P_{\mathrm{H}_{2} \mathrm{O}}\right)=0.293$.

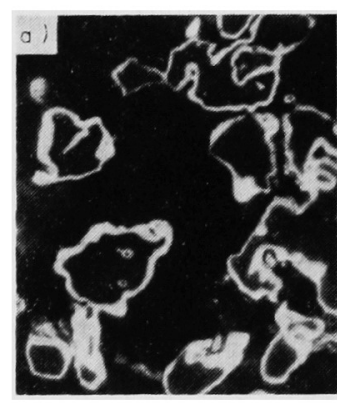

a) $X_{\mathrm{HI}}=0.64$

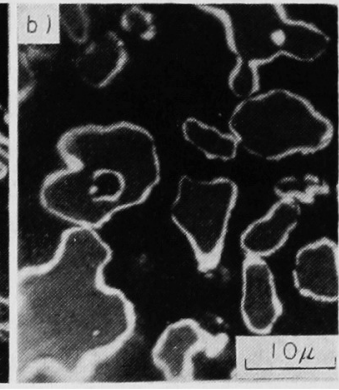

b) $X_{\mathrm{HI}}=0.58$
Photo. 2. Sectional views after partial reduction of pre-reduced magnetite, when reduced subsequently by the mixture of (a) $P_{\mathrm{H}_{2} \mathrm{O}} /\left(P_{\mathrm{H}_{2}}+P_{\mathrm{H}_{2} \mathrm{O}}\right)=0.0152$ and of (b) $P_{\mathrm{H}_{2} \mathrm{O}} /\left(P_{\mathrm{H}_{2}}+P_{\mathrm{H}_{2} \mathrm{O}}\right)=0.293$.
$\left.P_{\mathrm{H}_{2} \mathrm{O}}\right)=0.0152$ のもとでヘマタイト微粒子を予備還元し ないで直接に鉄をで還元を行なつたときの還元率 $X_{\mathrm{HI}}$ $=0.63$ における鉄の生成の状態を示したものである.

すでに前報6)で述べたように白色の金属鉄が黑色のウス タイトの楇围を取り围み，両者の界面は明確であり，反 応は殻状的に進行している. Photo. 1-b) に示した水 蒸気濃度が $P_{\mathrm{H}_{2} \mathrm{O}} /\left(P_{\mathrm{H}_{2}}+P_{\mathrm{H}_{2} \mathrm{O}}\right)=0.293$ と高い混合ガス で還元した場合にも，金属鉄とウスタイトの界面は Photo. 1-a) と同様にはつきりとしているが,生成鉄の 厚みは不均一であり，還元が全く進んでいない表面も一 部分認められた。さらに水蒸気濃度を $P_{\mathrm{H}_{2} \mathrm{O}} /\left(P_{\mathrm{H}_{2}}+P_{\mathrm{H}_{2} \mathrm{O}}\right)$ $=0.336$ と増していくと，その傾向がより顕著に現われ た.このような不均一な反応の進行がシグモイド型の還 元率曲線と対応していることは前報6)で報告した.

Photo. 2-a ) はへマタイトを $X_{\mathrm{HI}}=0.11$ のマグネタ イトまで予備還元し,引続き Photo. 1-a ) と同じ $P_{\mathrm{H}_{2} \mathrm{O}} /$ $\left(P_{\mathrm{H}_{2}}+P_{\mathrm{H}_{2} \mathrm{O}}\right)=0.0152$ の水蒸気分圧で 鉄へと 還元を行

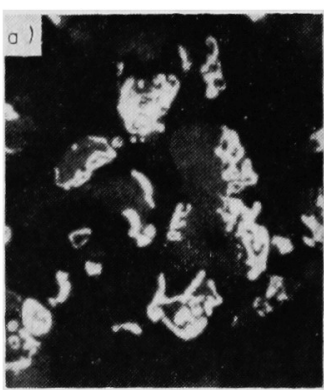

a) $X_{\mathrm{HI}}=0.58$

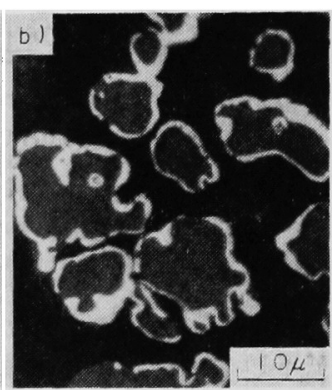

b) $X_{\mathrm{HI}}=0.60$
Photo. 3. Sectional views after partial reduction of pre-reduced wustite, $\mathrm{Fe}_{\mathbf{0} .89} \mathrm{O}$, when reduced subseqently by the mixture of (a) $P_{\mathrm{H}_{2} \mathrm{O}} /\left(P_{\mathrm{H}_{2}}+P_{\mathrm{H}_{2} \mathrm{O}}\right)=0.0152$ and of (b) $P_{\mathrm{H}_{2} \mathrm{O}} /\left(P_{\mathrm{H}_{2}}+P_{\mathrm{H}_{2} \mathrm{O}}\right)=0.293$.

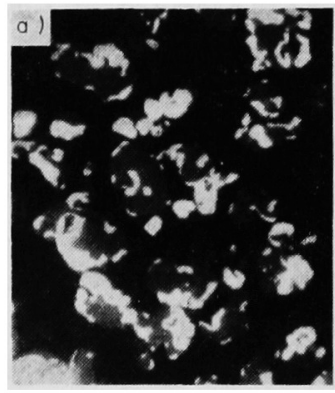

a) $X_{\mathrm{HI}}=0.60$

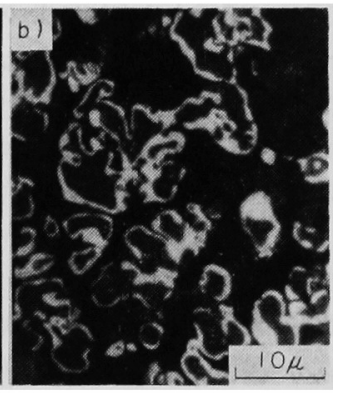

b ) $X_{\mathrm{HI}}=0.58$
Photo. 4. Sectional views after partial reduction of pre-reduced wustite, $\mathrm{Fe}_{0.95} \mathrm{O}$, when reduced subsequently by the mixture of (a) $P_{\mathrm{H}_{2} \mathrm{O}} /\left(P_{\mathrm{H}_{2}}+P_{\mathrm{H}_{2} \mathrm{O}}\right)=0.0152$ and of (b) $P_{\mathrm{H}_{2} \mathrm{O}} /\left(P_{\mathrm{H}_{2}}+P_{\mathrm{H}_{2} \mathrm{O}}\right)=0.293$. 
なつたときの結果であり, Photo. 2-b ) はそれより高い 水蒸気分圧 $P_{\mathrm{H}_{2} \mathrm{O}} /\left(P_{\mathrm{H}_{2}}+P_{\mathrm{H}_{2} \mathrm{O}}\right)=0.293$ で還元を行なつ たときの結果である. Photo. 1-a), b) とほぼ同様な 傾向を示しているが，金属鉄の生成が局部的に進行して いるところがやや多く見られる.

$X_{\mathrm{HI}}=0.25$ のウスタイト $\left(\mathrm{Fe}_{0.89} \mathrm{O}\right)$ 及び $X_{\mathrm{HI}}=0.30$ のウスタイト $\left(\mathrm{Fe}_{0.95} \mathrm{O}\right)$ まで予備還元を行ない, 引続い て水蒸気濃度の低い $P_{\mathrm{H}_{2} \mathrm{O}} /\left(P_{\mathrm{H}_{2}}+P_{\mathrm{H}_{2} \mathrm{O}}\right)=0.0152$ の混合 ガスで還元を行なつた場合をそれぞれ Photo. 3-a)， Photo. 4- a ）に示したが, これらの場合には粒子の表面 全体が金属鉄に覆われないうちに局部的な金属鉄の生成 が見られる. $\mathrm{KOHL}^{8)}$ ，小野田9)らは前もつて調整したウ スタイト試料の鉄への反応において同栐な現象を観察し ている.

一方, ウスタイトまで備還元した後, 水蒸気濃度が 高い $P_{\mathrm{H}_{2} \mathrm{O}} /\left(P_{\mathrm{H}_{2}}+P_{\mathrm{H}_{2} \mathrm{O}}\right)=0.293$ の混合ガスで還元を行 なつた場合の Photo. 3-b), Photo. 4-b) を見ると生 成鉄の厚みが均一ではなく，いまだに還元が全く進んで いない表面も一部分認められるが，Photo. 3-a ), 4-a ) に比較するとほぼ白い金属鉄が黑いウスタイトを取り围 むように反応が進行している.このように水蒸気濃度が 高くなると鉄の生成のようすがをつたく違つてくる．永 来, 水蒸気濃度が高い条件下での研究はみあたらず, 鉄 の生成状態のメカニズムを考元るためにもこのような条 件下でのさらに詳細な研究が望まれる.

\section{4. 結論}

平均径 $8.1 \mu$ の焼結へマタイト微粒子のマグネタイト あるいはウスタイト $\left(\mathrm{Fe}_{0.89} \mathrm{O}, \mathrm{Fe}_{0.95} \mathrm{O}\right)$ までの予備還 元が引続いて起こる鉄への還元におよぼす影響について 検討を行なつた. 予備還元ならびにその後の還元は 900 ${ }^{\circ} \mathrm{C}$ の温度で行なつた，しかし, 混合ガス中の水素と水 蒸気の分圧比は広範囲にわたつてかえた。交た，予備還 元後ただちに鉄への還元を行なうことができるようとく に実験装置を工夫した。
ヘマタイト微粒子をマグネタイトまで子借還元すると ウスタイトから鉄への還元速度のみならザマグネタイト からウスタイトへの還元速度も著しく低下した．そして ウスタイトー鉄の界面は子備還元なしの場合上同様に卜 ポケミカル的に進行した。

ヘマタイト微粒子をウスタイトまで予備還元すると， 予備還元なしの場合に比べてかなり高い邆元速度が得ら れ，その傾向は上くに水素浱度が高い場合に顕著に現わ れた、また，このような条件下ではウスタイトから鉄へ の反応はトホヶミカル的には進まなかつた．しかし，水 蒸気濃度が高くなると還元速度も予備還元なしの場合と 大差なくなり，また反応もむしろトポケミカル的に進行 した。

ウスタイトから鉄への還元速度を水素と水蒸気濃度と の比に対して各子備還元についてプロットし，それらの 困を比較してみると，予備還元によつてウスタイト-鉄 の平衡が見かけ上水素濃度の高い方に移動していくこと がわかつた。

\section{交献}

1) $Y$. Nakano, $M$. Ishida, $T$. Akehata, and $T$. Shirai: Met. Trans., 6B(1975), p. 429

2) R. H. Tien and E. T. Turkdogan: Met. Trans., 3 (1972), p. 2028

3 ) J. O. EDström: JISI, 175(1953), p. 289

4) G. NABI and $W . K$. Lu: Trans. Met. Soc. AIME, 242(1968), p. 2471

$5) J . M$. Quets, M.E. WAdWorth, and $J . R$. LEwIS: Trans. Met. Soc. AIME, 221 (1961), p. 1186

6 ) 中野, 石田, 白井: 鉄と鋼, 60 (1974), p. 20

7 ) L. S. Darken and $R$. W. Gurry: J. Amer. Chem. Soc., 67(1945), p. 1398, 68 (1946), p. 798

$8)$ H. K. KoHL and H.J. ENGEL: Arch. Eisenhüttenw., 34(1963), p. 411

9 ) 小野田, 德田, 大谷：鉄と罁，54(1968) 3, S 33 